originality in getting itself hunted, as related by its owner in the Journal of Mammalogy for February, p. 41. Its habit, as it was allowed complete liberty, was to go to the main street of the little town and entice dogs to pursue it; the resulting hunt might last as long as three-quarters of an hour, at the discretion of the doe, which had so much the advantage of her pursuers in speed and intelligence that she did as she liked with them, fleeing in pretended fear, circling and waiting for them to come up, and then darting off in the opposite direction, until at last she left the pack behind and went home. It is satisfactory to learn that she came to no harm and was ultimately sent to a park and bore twins; but it would be interesting to know if playing at being hunted is a recreation indulged in by animals we usually regard as food for others, when they live in the natural state. That the hunters may play at hunting we know from what has been observed of the puma and the peregrine falcon.

\section{Excavations in Texas Caves}

THE Smithsonian Institution, it is announced through Science Service, of Washington, D.C., is sending an expedition to the caves of western Texas in charge of Mr. Frank M. Setzler, staff archæologist. The object of the expedition is to obtain evidence of the culture of the early cave dwellers of this area, and if possible to ascertain their relation to the basket makers who preceded the Pueblo-Indians of the southwestern states. Traces of the basket-makers' culture have already been found in Texas caves, but there is also evidence, in spear points of stone associated with the bones of extinct animals at some depth below the earliest basket-maker relics, of an earlier people.

\section{Modern Aids to Teaching}

A QUARTERLY review of modern aids to teaching, entitled Sight and Sound, has been published under the auspices of the British Institute of Adult Education. The first issue contains thirty pages, and is illustrated. It is edited by a committee appointed by the Institute, and its purpose is to promote in terest in the use of modern scientific inventions, such as the film, gramophone, wireless, and television, in schools and colleges and in general cultural work The gramophone and wireless have already shown their usefulness in the teaching of languages and music ; one of the articles in the issue maintains that the teaching film should be planned, made, and used in the school.

\section{New Physical Apparatus}

In their new catalogue, No. 115X, of forty pages, Messrs. Griffin and Tatlock, Ltd., give an account of some new models of physical apparatus designed for use in the teaching of physics. Under the name Microid Physical Series some twenty new designs have been produced, based for the most part on modern research methods. Each apparatus is described in a 'specification', and this is followed by 'experimental notes' which will be useful to the teacher and the student, especially as in many cases numerical results from an actual experiment are quoted. As indicating the type of apparatus included, mention may be made of the microcel thermopile, the thermo-magnet illustrating the heavy currents obtainable from thermo-elements under suitable conditions, the magnetic potentiometer (Chattock), and the moment of inertia apparatus with rotating table. Experiments are also included on light, such as the parallel plate refractometer, and heat, such as the micrometer expansion apparatus, to mention only a few of the methods described. References are given to the textbooks of Pohl, Searle, and Worsnop and Flint. Teachers of physics will find here many suggestive hints for experimental work.

\section{Announcements}

Dr. Dukinfiend H. ScotT, F.R.S., the eminent palæobotanist, has been elected a corresponding member of the Prussian Academy of Sciences.

The Faraday Medal of the Institution of Electrical Engineers will be presented to Sir Oliver Lodge at the ordinary meeting of the Institution to be held on April 21 at 6 P.M. The presentation will precede the twenty-third Kelvin Lecture, which will be delivered by Dr. W. E. Sumpner, on "The Work of Oliver Heaviside".

UNDER the auspices of the British Science Guild, Prof. S. Chapman, professor of mathematics at the Imperial College of Science and Technology, will deliver a popular lecture on "Polar Lights", on Wednesday, May 25, at 5 P.M. The lecture will be at the Royal Society of Arts, John Street, Adelphi, W.C.2. Tickets, for which no charge is made, can be obtained on application to the Secretary, British Science Guild, 6 John Street, Adelphi, W.C.2.

The Dyers' Company Gold Research Medal for the period 1930-31 has been awarded to Prof: F. M. Rowe, professor of colour chemistry and dyeing in the University of Leeds, for a series of three papers on the chemical and physical effects of kier boiling on insoluble azo colours on the fibre. This is the third occasion on which Prof. Rowe has received this medal, the earlier awards being made for the periods 1924-25 and 1926-27 for his investigations of other aspects of the chemistry of azo colouring matters.

Prof. W. L. BragG, F.R.S., professor of physics, Victoria University of Manchester ; the Rev. Canon H. Maynard Smith, Canon Residentiary of Gloucester ; and the Right Hon. J. H. Whitley, chairman of the British Broadcasting Corporation, formerly Speaker of the House of Commons, have been elected members of the Athenæum under the provisions of Rule II. of the Club, which empowers the annual election by the committee of a certain number of persons of distinguished eminence in science, literature, the arts, or for public service.

THE following appointments to the Colonial Agricultural Service have recently been made by the Secretary of State: Mr. W. E. Bassett, formerly assistant superintendent, Victoria Botanic Gardens, Nigeria, to be assistant agricultural officer, Dominica ; Mr. T. R. Hayes, superintendent of agriculture, Gambia, to be agricultural officer, Uganda; $\mathrm{Mr}$. F. L. Squibbs, assistant agricultural officer, Leeward 
Islands, to be assistant director of agriculture, Seychelles ; and Mr. I. G. C. Squire, assistant manager, Oil Palm Plantations, Sierra Leone, to be manager, Government Plantations, Zanzibar.

THe American Association for the Advancement of Science will hold its second summer meeting at Syracuse, New York, on June 20-25. The third summer meeting will be held at Chicago in connexion with the Century of Progress World's Fair on June 19-30, 1933. The centre of this meeting at the World's Fair will be the Hall of Science, in which nearly ten acres of floor space will be devoted to science exhibits. Seventy-five European men of science will be invited to attend this meeting as guests of the American Association.

The twenty-second annual May lecture of the In. stitute of Metals will be delivered by Dr. F. Körber, director of the Kaiser-Wilhelm-Institut für Eisenforschung, Düsseldorf, on Wednesday, May 11, at 8 P.M., at the Institution of Mechanical Engineers, Storey's Gate, Westminster, London, S.W.1, the subject of the lecture being "The Plastic Deformation of Metals". Cards of invitation may be obtained from Mr. G. Shaw Scott, 36 Victoria Street, S.W.1.

THE amalgamation of the Optical Society and the Physical Society of London has been under consideration for sorne time. It has now been decided to proceed with the amalgamation. Certain alterations are to be made in the articles of association of the Physical Society, and, in due course, a general meeting of the Optical Society will be held to wind up the Society.

FARMER' and farm workers' associations and clubs, chambers of agriculture and horticulture, students' societies, and other bodies interested in agriculture or market gardening are invited to inspect the Rotham. sted and Woburn Experimental Plots during the coming summer. Mr. H. V. Garner and Capt. E. H. Gregory will be available to demonstrate the plots. All communications and requests to visit the Stations should be addressed to the Secretary, Rothamsted Experimental Station, Harpenden.

The autumn meeting of the Iron and Steel Institute will be held in London on Sept. 13-15, concurrently with that of the Institute of Metals. It has been provisionally decided that at least one joint session shall be held at which papers of interest to the members of both Institutes shall be presented and discussed. Other sessions will be held separately but concurrently.

$\mathrm{AT}_{\mathrm{T}}$ the recent annual meeting of the Institution of Automobile Engineers, Major C. G. Nevatt was elected president of the Institution for the session 1932-33. The summer visit of the members of the Institution will this year take the form of a four days' trip up the Thames to Oxford on June 8-11, including visits to Morris Motors, Ltd., and the Pressed Steel Works of Great Britain.

ANother of the valuable catalogues (No. 456) of Messr's. Bernard Quaritch, Ltd., 11 Grafton Street, W.1, has reached us. It deals with nearly 1500 works on zoology, geology, and palæontology, and should be

No. 3259, VoL. 129] of interest to students of these branches of science and to librarians.

Messrs. Bowes and Bowes, 1 Trinity Street, Cambridge, have just published a catalogue (No. 461) entitled "Old-time Literature (a third Catalogue), principally of XVIIth and XVIIIth centuries", containing particulars of nearly 1700 second-hand books on a variety of subjects, several of which relate to scientific matters.

THe following books are announced for early publication by Messrs. Longmans and Co., Ltd. : "The Causes of Evolution", Prof. J. B. S. Haldane ; "A Manual of the Flowering Plants and Ferns of the Transvaal, with Swaziland, South Africa", Dr. J. Burtt Davy-Part 2, "Malvaceæ to Umbelliferæ" (completing the Archichlamyder); "Modern Methods in Quantitative Chemical Analysis", Drs. A. D. Mitchell and A. M. Ward; "Modern Practice in Mining ", Sir Richard Redmayne-Vol. 5, " Colliery Machinery and its Application"; "Steam Engine Theory and Practice", Prof. W. Ripper, new and revised edition, edited by Prof. W. J. Goudie; "Elements of Stearn Power Engineering", Dr. O. Sneeden, and "Graphical Geometry", E. N. Digweed.

ApPLICATIONs are invited for the following appointments, on or before the dates mentioned:-Male laboratory assistants, Grade II., at the Royal Arsenal -The War Department Chemist, B.47, Royal Arsenal, Woolwich, S.E.18 (April 23). A veterinary assistant at the Veterinary Laboratory of the Ministry of Agriculture and Fisheries, New Haw, WeybridgeThe Secretary, Ministry of Agriculture and Fisheries, 10 Whitehall Place, S.W.1 (April 25). An assistant master at the Mining and Technical Institute and Junior Technical Day School, Neath, with a degree in engineering and works experience in engineeringThe Director of Education, County Hall, Cardiff (April 25). A woman demonstrator in inorganic and physical chemistry at the Bedford College for Women - The Secretary, Bedford College for Women, Regent's Park, N.W.1 (April 30). A lecturer in botany at the Wigan and District Mining and Technical College--The Principal, Wigan and District Mining and Technical College, Wigan (May 2). An intelligence officer in the Engineering and Metals Section of the Department of Overseas Trade-The Chief Establishment Officer, Department of Overseas Trade, 35 Old Queen Street, Westminster, S.W.1 (May 5). Assistant civil engineers in the Civil Engineer-in-Chief's Department, Admiralty, and H.M. naval establishments at home and abroad-The Civil Engineer-in-Chief, Admiralty, S.W.1 (May 14). An assistant master at the Leyton Technical College, with a degree in engineering or its equivalent and experience in teaching--R. J. Geldart, 280 High Road, Leyton, E.10. An assistant chemist under the Research Association of British Paint, Colour, and Varnish Manufacturers - The Paint Research Station, Teddington, Middlesex. A laboratory steward in the Department of Physics of St. Thomas's Hospital Medical School-Dr. J. H. Brinkworth, Physics Department, Medical School, St. Thomas's Hospital, S.E.I. 